\section{Nauplius}

The Journal OF The

Brazilian Crustacean Society

e-ISSN 2358-2936

www.scielo.br/nau www.crustacea.org.br

\title{
Tracking of spatial changes in the structure of the zooplankton community according to multiple abiotic factors along a hypersaline lagoon
}

Judson da Cruz Lopes da Rosa' ${ }^{1}$ (D) orcid.org/0000-0001-7635-8736

Lucas Lemos Batista ${ }^{2}$ (D) orcid.org/0000-0003-2389-7132

Wanda Maria Monteiro-Ribas ${ }^{3}$ (D) orcid.org/0000-0002-1228-2805

1 Programa de Pós-Graduação em Ciências Ambientais e Conservação, Laboratório Integrado de Zoologia na Universidade Federal do Rio de Janeiro. Macaé, Rio de Janeiro, Brazil.

JCLR E-mail: judsoncruz@yahoo.com.br

2 Programa de Pós-Graduação em Ciências Ambientais e Conservação, Laboratório de Invertebrados na Universidade Federal do Rio de Janeiro. Macaé, Rio de Janeiro, Brazil.

LLB E-mail: lucaslemosb23@gmail.com

3 Instituto de Estudos do Mar Almirante Paulo Moreira, Departamento de Oceanografia, Divisão de Ecossistemas Marinhos. Arraial do Cabo, Rio de Janeiro, Brazil.

WMM-R E-mail: ribaswanda@gmail.com

ZOOBANK: http://zoobank.org/urn:lsid:zoobank.org:pub:E68D1C4A-AC4F-40888882-160DDE68AF71

\section{ABstRact}

In this study we evaluated the effects of changes in salinity, temperature, $\mathrm{pH}$ and dissolved oxygen on the spatiotemporal variation of zooplankton. Samples were collected in January-March, May; October-December 2010; and January-March 2011 in the Araruama lagoon, state of Rio de Janeiro, Brazil. There were eight fixed stations sampled using a WP2 net equipped with a flow meter. The zooplankton diversity of the Araruama lagoon was low and dominated by Cirripedia larvae and by the copepod Acartia tonsa, which is an indicator species of eutrophication. In general, a few species from the Cabo Frio region were able to adapt to the conditions of this hypersaline lagoon. In addition, a specimen of Monstrilla bahiana (Monstrilloidae) was found at a salinity of $46 \%$. This is the first record of the order Monstrilloida in the region of Cabo Frio. Temperature, salinity and $\mathrm{pH}$ were shown to be

CORRESPONDING AUTHOR Judson da Cruz Lopes da Rosa judsoncruz@yahoo.com.br

SUBMITTED 06 April 2019 ACCEPTED 20 February 2020 PUBLISHED 03 June 2020

\section{(cc) BY}

All content of the journal, except where identified, is licensed under a Creative Commons attribution-type BY.

Nauplius, 28: e2020012 


\section{INTRODUCTION}

Hypersaline marine ecosystems are very limited in extent in Brazil and worldwide and have been poorly studied (Cotner, 2004). Brazil has a few hypersaline water bodies such as the Araruama lagoon, Pernambuca lagoon and Vermelha lagoon, Mossoró river (Silva et al., 2004a; Silva et al., 2004b; Serpe et al., 2010). A striking feature of Araruama lagoon is its high salinity, which is twice that of seawater. The high salinity allows the extraction of natural salt, a traditional activity in the region (Coutinho et al., 1999; Carvalho et al., 2014).

In Brazil, many aquatic environments are polluted with untreated sewage (Aslan et al., 2017), bays and estuaries are some of the most affected environments (Coelho-Botelho et al., 1999; Pereira, 2007; Carvalho et al., 2014; Costa, 2015). Since the 1980s, the Araruama lagoon has been subjected to sewage contamination (Pereira, 2007) due to an increased number of summer tourists and growth of the resident populations of Araruama and neighboring towns (Coutinho et al., 1999; Pereira, 2007; Carvalho et al., 2014). The continuous discharge of sewage in the lagoon has decreased the salinity and increased the nutrient loading (Souza et al., 2003; Rosa et al.,2016a). After many years of sewage discharge, Araruama is now considered as an eutrophic lagoon (Carvalho et al., 2014). Moreover, its average salinity is currently $41 \%$, which is higher than that of the sea of Cabo Frio where the lagoon water exchange occurs (Rosa et al., 2016a).

Eutrophication influences the planktonic community (Costa et al., 2018), and globally, the zooplankton community of hypersaline environments is usually poor in diversity and abundance. Indeed, in a previous study at the Araruama lagoon the copepod assembly was represented by three taxa only (Coutinho et al., 1999), whereas the copepod assembly of the adjacent Cabo Frio region has 39 taxa (Rosa et al., 2016b). The present study aimed to evaluate whether abiotic factors influence the spatial and temporal variation of zooplankton in the Araruama lagoon, and to compare the zooplankton diversity with the assembly of copepods of Cabo Frio, to understand which species of the region can adapt to the extreme conditions of the lagoon.

\section{Materials And Methods}

\section{Study area}

The Araruama lagoon occupies $210 \mathrm{~km}^{2}$ and is located on the coast of the state of Rio de Janeiro, Brazil, between latitudes $22^{\circ} 40^{\prime} \mathrm{S}$ and $22^{\circ} 57^{\prime} \mathrm{S}$ and longitudes $42^{\circ} 00^{\prime} \mathrm{W}$ and $42^{\circ} 23^{\prime} \mathrm{W}$ (Castro et al., 1999). The lagoon is bound by the following cities: Araruama, Arraial do Cabo, Cabo Frio, São Pedro da Aldeia and Iguaba (Carvalho et al.,2014). One of the main characteristics of the lagoon is its high salinity, due to its size (around $200 \mathrm{~km}^{2}$ ).

\section{Sampling}

Abundance and zooplankton composition was obtained in eight sites chosen according to their proximity to sewage discharges: Boqueirão (station 1), Monte Alto (station 2), Centro de São Pedro da Aldeia (station 3), Enseada de Iguaba (station 4), Ponta do Acaíra (station 5), Barbudo (station 6), Centro de Araruama (station 7) and Ponta dos Excursionistas (station 8) (Fig. 1). The highest discharge of untreated sewage occurs at stations 2,3 and 7.

In 2010, samples were taken monthly from January to June, October to December, and in 2011, from January to March. During the data sampling, the state of the tide (ebb or flood) could not be standardized at the time of sampling, but previous data reveal that the tide has no significant influence on salinity from the Boqueirão sampling site (station 1) to Ponta dos Excursionistas (station 8) (Rosa et al., 2016a). However, the general scenario of tidal trends ranged between ebb and flood (January $2010 \mathrm{ebb}$; February $2010 \mathrm{ebb}$; March 2010 ebb; May 2010 flood; October 2010 ebb; November 2010 ebb; December 2010 flood; January 2011 ebb; February 2011 ebb; March 2011 flood). The tide data was obtained from the site of the Brazilian Navy (https://www.marinha.mil.br/chm/) (Centro de Hidrografia da Marinha, Marinha do Brasil).

Eight samples were taken per site at each month, giving a total of 80 samples collected by means of horizontal surface hauls with a net with a $60 \mathrm{~cm}$ diameter, $200 \mu \mathrm{m}$ mesh and coupled flowmeter. The samples were fixed in a $4 \%$ formalin solution diluted with water from the lagoon previously neutralized with sodium tetraborate.

The abundance of zooplankton (individuals. $\mathrm{m}^{-3}$ ) was estimated using Stempel pipette subsampling 


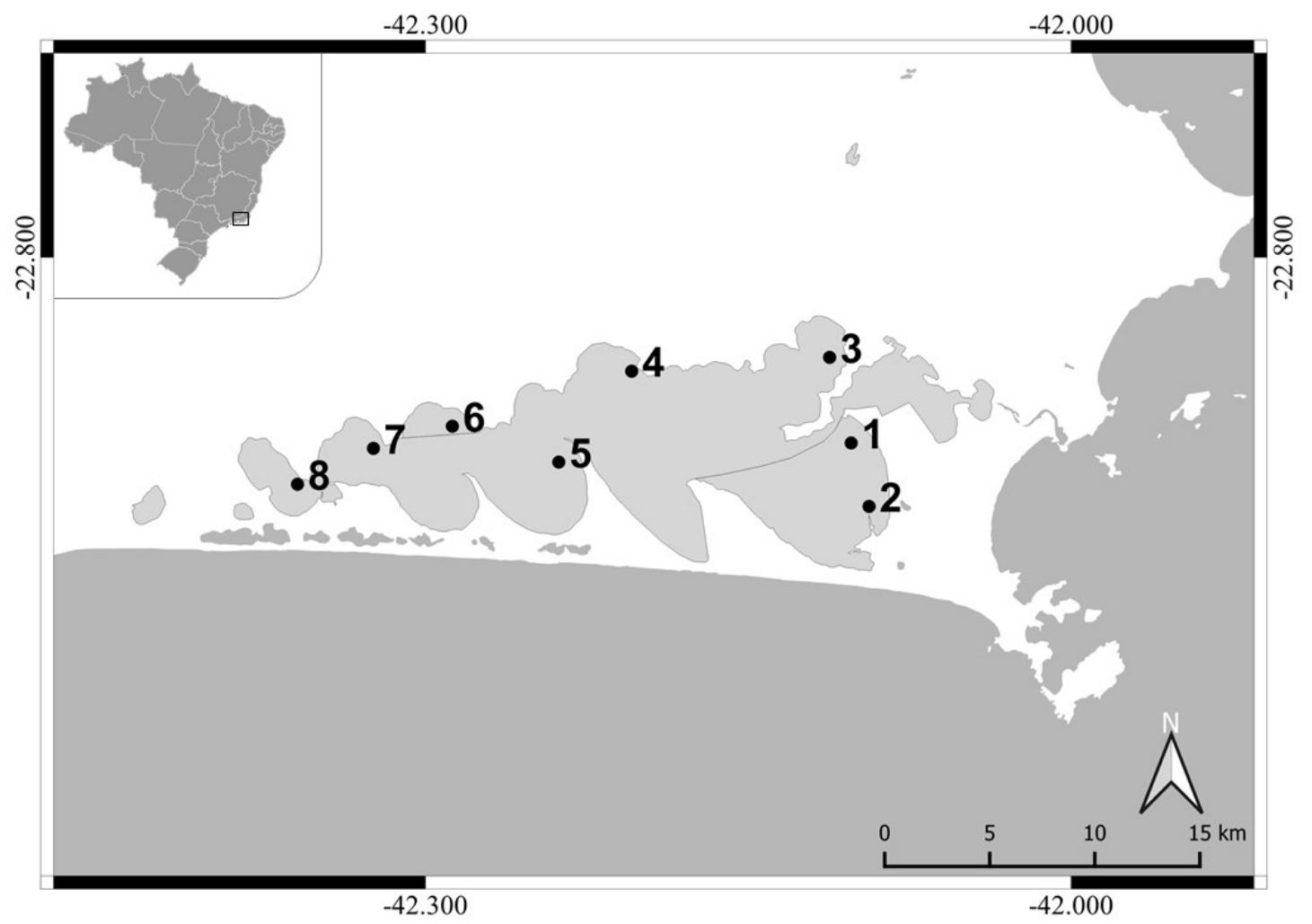

Figure 1. Map of the coast of the state of Rio de Janeiro pointing out the 8 sampling stations of the Araruama lagoon.

(2.68 $\mathrm{ml})$. Taxonomy and species ecology were based on Boltovskoy $(1981 ; 1999)$. To evaluate the potential effect of continental runoff upon plankton abundance, major environmental parameters, namely salinity, temperature, dissolved oxygen $\left(\mathrm{mg}^{-\mathrm{L}^{-1}}\right)$ and $\mathrm{pH}$, were measured. For analysis of abiotic data the water samples were measured in the field and with a single value for each parameter, except $\mathrm{pH}$, which was measured in the laboratory. The salinity was measured by a refractometer, temperature and oxygen dissolved by a portable oximeter (ITT datalogger 71440) and $\mathrm{pH}$ was measured by a portable $\mathrm{pH}$ meter (SKU: SP3630-45). These parameters were considered related to the continental flow, mainly discharge of sewage in estuaries and bays (Pereira, 2007).

\section{Data analysis}

The community structure was described in terms of the Shannon-Weaver diversity index $\left(\mathrm{H}^{\prime}\right)$ and the Pielou's uniformity index $\left(J^{\prime}\right)$. To evaluate the effects of the abiotic data on the zooplankton community, the relative abundance of the organisms with the highest frequency of occurrence were correlated (linear regression) with temperature, salinity, and $\mathrm{pH}$.
A multiple regression was performed in order to understand which parameter(s) (temperature, salinity, and $\mathrm{pH}$ ) most influenced the abundance of Cirripedia and Acartia tonsa. We also used a correlation to investigate the temporal variation in the relative abundance of Cirripedia with that of the copepod Acartia tonsa. From the linear regression results, the month of May 2010 was chosen to make the multiple regression, since this month the larvae correlated well with the three parameters (temperature, salinity, and $\mathrm{pH}$ ).

\section{Results}

Salinity ranged seasonally from $42 \%$ in autumn (May 2010) to 53\%o in summer (February 2010), with an annual average of $45 \%$. The lowest temperature was recorded in October $2010\left(23.3^{\circ} \mathrm{C}\right)$, and the highest, in January $2010\left(32.1^{\circ} \mathrm{C}\right)$. Mean annual temperature was $27.9^{\circ} \mathrm{C}$. Dissolved oxygen ranged from 3.08 to 10 mg.L. ${ }^{-1}$ with an overall average of $6.36 \mathrm{mg} . \mathrm{L}^{-1}$, while $\mathrm{pH}$ was lower in February 2011 (6.2) and higher in January 2010 (9.3). The overall average $\mathrm{pH}$ was 8.15 (Fig. 2). 

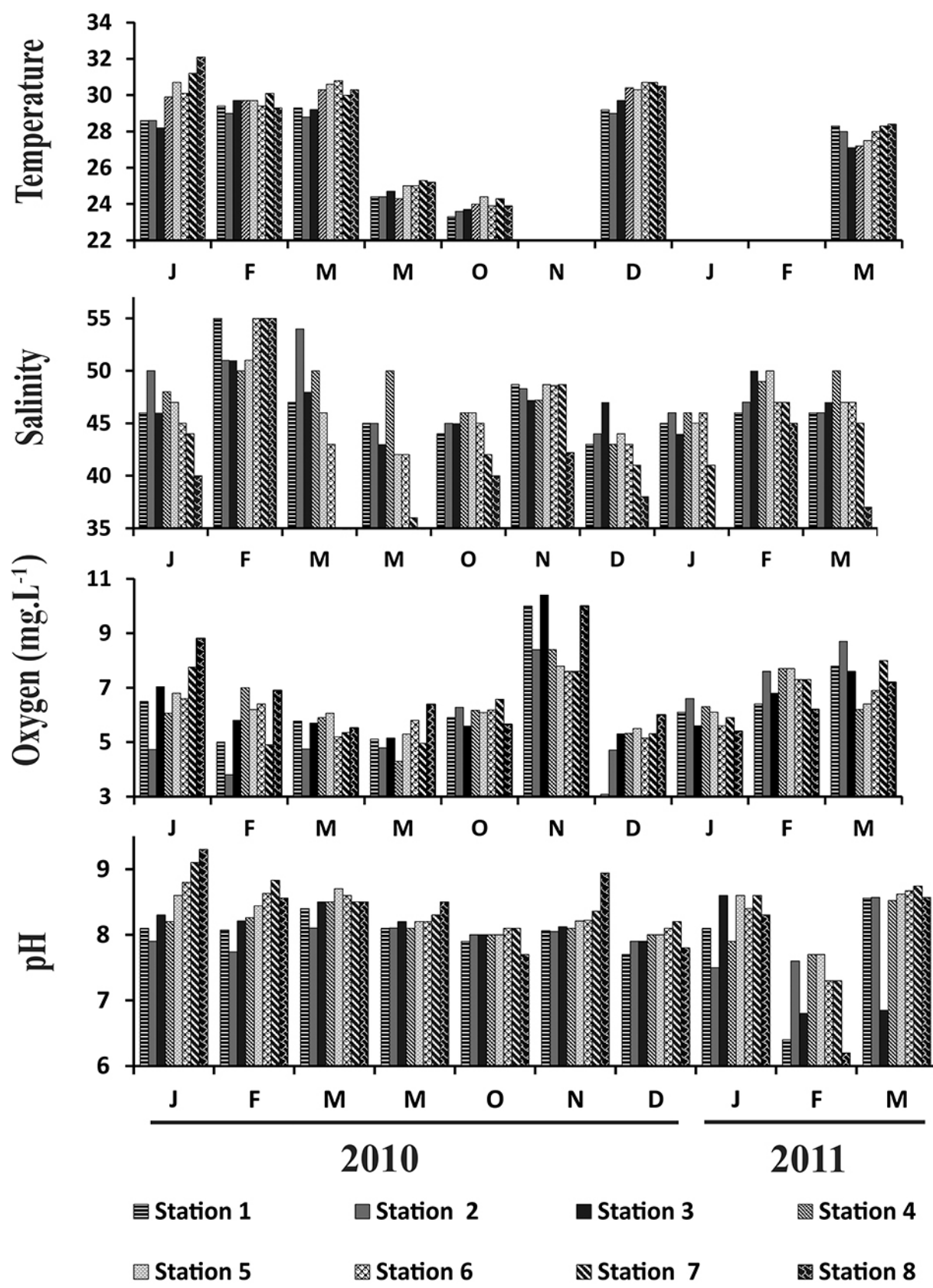

Figure 2. Variation of multiple factors (temperature, salinity, oxygen $\left(\mathrm{mg} \cdot \mathrm{L}^{-1}\right)$, and $\mathrm{pH}$ ) in each collection station over the sampled months of 2010 and 2011.

The temperature, salinity, oxygen, and $\mathrm{pH}$ influenced the spatial variation of the larvae of Cirripedia in Araruama lagoon: at lower temperatures and $\mathrm{pH}$ and higher salinity the density of the Cirripedia larvae was higher. There was a negative correlation between temperature and $\mathrm{pH}$ and Cirripedia larvae abundance in terms of spatial variation and a positive correlation between salinity and Cirripedia larvae abundance (Tab. 1 and Fig. 3). The multiple regression analysis indicated that the three variables (temperature, salinity, and $\mathrm{pH}$ ) had the greatest influence on the spatial variation of Cirripedia larvae $\left(\mathrm{R}^{2}\right.$ adj $\left.=-0.67, \mathrm{p}=0.00\right)$. In the spatial correlation between $A$. tonsa and abiotic data no significant results were found. (Tab. 2). However, A. tons $a$ had a negative correlation with temperature $\left(R^{2}=-0.68 ; p=0.02\right)$, but for the other parameters no correlations were found. For the Cirripedia larvae, no significant results were found for temporal variation (Tab. 3). The density of $A$. tonsa was correlated with that of Cirripedia larvae $\left(\mathrm{R}^{2}=0.52 ; \mathrm{p}=0.02\right)$ (Fig. 4). 

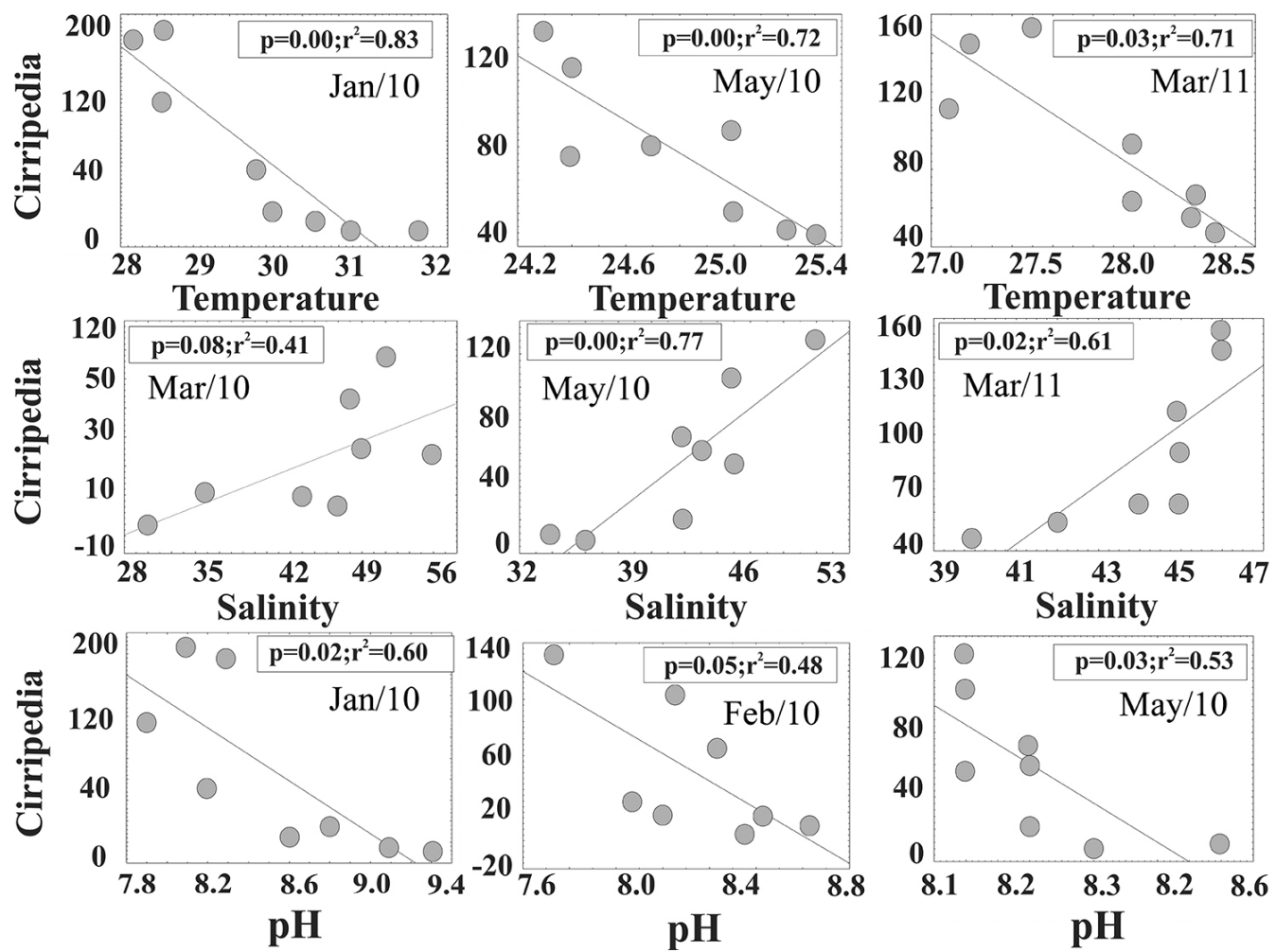

Figure 3. Relationship between temperature, salinity, and $\mathrm{pH}$ and their effect on the abundance of Cirripedia larvae over the months.

Table 1. Spatial variation correlations between abiotic data (Temperature, Salinity, and $\mathrm{pH}$ ) and Cirripedia larvae over the sampled months.

\begin{tabular}{|c|c|c|c|}
\hline Months & Temperature & Salinity & pH \\
\hline Jan/2010 & $R^{2}=-0.83 ; p=0.00$ & $\mathrm{R}^{2}=0.19 ; \mathrm{p}=0.26$ & $R^{2}=-0.60 ; p=0.02$ \\
\hline $\mathrm{Feb} / 2010$ & $\mathrm{R}^{2}=-0.14 ; \mathrm{p}=0.36$ & $R^{2}=-0.55 ; p=0.03$ & $R^{2}=-0.48 ; p=0.05$ \\
\hline Mar/2010 & $\mathrm{R}^{2}=-0.12 ; \mathrm{p}=0.39$ & $\mathrm{R}^{2}=0.41 ; \mathrm{p}=0.08$ & $\mathrm{R}^{2}=-0.08 ; \mathrm{p}=0.48$ \\
\hline May/2010 & $R^{2}=-0.72 ; p=0.00$ & $R^{2}=0.77 ; p=0.03$ & $R^{2}=0.53 ; p=0.03$ \\
\hline Oct $/ 2010$ & $\mathrm{R}^{2}=0.10 ; \mathrm{p}=0.42$ & $R^{2}=0.61 ; p=0.02$ & $\mathrm{R}^{2}=0.07 ; \mathrm{p}=0.51$ \\
\hline Nov/2010 & - & $\mathrm{R}^{2}=0.01 ; \mathrm{p}=0.76$ & $\mathrm{R}^{2}=0.07 ; \mathrm{p}=0.49$ \\
\hline Dec/2010 & $\mathrm{R}^{2}=0.10 ; \mathrm{p}=0.42$ & $\mathrm{R}^{2}=0.00 ; \mathrm{p}=0.82$ & $\mathrm{R}^{2}=0.02 ; \mathrm{p}=0.42$ \\
\hline Jan/2011 & - & $\mathrm{R}^{2}=0.16 ; \mathrm{p}=0.31$ & $\mathrm{R}^{2}=0.05 ; \mathrm{p}=0.57$ \\
\hline $\mathrm{Feb} / 2011$ & - & $\mathrm{R}^{2}=0.02 ; \mathrm{p}=0.70$ & $\mathrm{R}^{2}=0.03 ; \mathrm{p}=0.66$ \\
\hline Mar/2011 & $R^{2}=-0.71 ; p=0.03$ & $\mathrm{R}^{2}=0.11 ; \mathrm{p}=0.40$ & $\mathrm{R}^{2}=0.01 ; \mathrm{p}=0.78$ \\
\hline
\end{tabular}

Table 2. Spatial variation correlations between abiotic data (Temperature, Salinity, and $\mathrm{pH}$ ) and Acartia tonsa over the sampled months.

\begin{tabular}{lccc}
\hline Months & Temperature & Salinity & pH \\
\hline Jan/2010 & $\mathrm{R}^{2}=-0.10 ; \mathrm{p}=0.43$ & $\mathrm{R}^{2}=-0.02 ; \mathrm{p}=0.69$ & $\mathrm{R}^{2}=-0.05 ; \mathrm{p}=0.58$ \\
Feb/2010 & $\mathrm{R}^{2}=0.00 ; \mathrm{p}=0.90$ & $\mathrm{R}^{2}=0.06 ; \mathrm{p}=0.54$ & $\mathrm{R}^{2}=0.00 ; \mathrm{p}=0.86$ \\
Mar/2010 & $\mathrm{R}^{2}=0.06 ; \mathrm{p}=0.54$ & $\mathrm{R}^{2}=0.04 ; \mathrm{p}=0.59$ & $\mathrm{R}^{2}=0.25 ; \mathrm{p}=0.19$ \\
May/2010 & $\mathrm{R}^{2}=-0.26 ; \mathrm{p}=0.19$ & $\mathrm{R}^{2}=0.21 ; \mathrm{p}=0.25$ & $\mathrm{R}^{2}=-0.21 ; \mathrm{p}=0.24$ \\
Oct/2010 & $\mathrm{R}^{2}=0.34 ; \mathrm{p}=0.12$ & $\mathrm{R}^{2}=0.20 ; \mathrm{p}=0.25$ & $\mathrm{R}^{2}=0.05 ; \mathrm{p}=0.58$ \\
Nov/2010 & - & $\mathrm{R}^{2}=0.00 ; \mathrm{p}=0.89$ & $\mathrm{R}^{2}=0,00 ; \mathrm{p}=0.77$ \\
Dec/2010 & $\mathrm{R}^{2}=0.01 ; \mathrm{p}=0,80$ & $\mathrm{R}^{2}=0.15 ; \mathrm{p}=0.34$ & $\mathrm{R}^{2}=0.00 ; \mathrm{p}=0.82$ \\
Jan/2011 & - & $\mathrm{R}^{2}=0.12 ; \mathrm{p}=0.39$ & $\mathrm{R}^{2}=-0.01 ; \mathrm{p}=0.74$ \\
Feb/2011 & - & $\mathrm{R}^{2}=0.21 ; \mathrm{p}=0.24$ & $\mathrm{R}^{2}=0.06 ; \mathrm{p}=0.53$ \\
Mar/2011 & $\mathrm{R}^{2}=0.39 ; \mathrm{p}=-.009$ & $\mathrm{R}^{2}=0.13 ; \mathrm{p}=0.36$ & $\mathrm{R}^{2}=0.06 ; \mathrm{p}=0.54$
\end{tabular}


Table 3. Correlations of temporal variations between abiotic data, Cirripedia and Acartia tonsa.

\begin{tabular}{lcc}
\hline Abiotic data & \multicolumn{1}{c}{ Cirripedia } & Acartia tonsa \\
\hline Temperature & $\mathrm{R}^{2}=-0.22 ; \mathrm{p}=0.28$ & $\mathrm{R}^{2}=-0.68 ; \mathrm{p}=0.02$ \\
Salinity & $\mathrm{R}^{2}=0.04 ; \mathrm{p}=0.54$ & $\mathrm{R}^{2}=-0.04 ; \mathrm{p}=0.56$ \\
$\mathrm{pH}$ & $\mathrm{R}^{2}=-0.08 ; \mathrm{p}=0.40$ & $\mathrm{R}^{2}=-0.08 ; \mathrm{p}=0.40$ \\
\hline
\end{tabular}
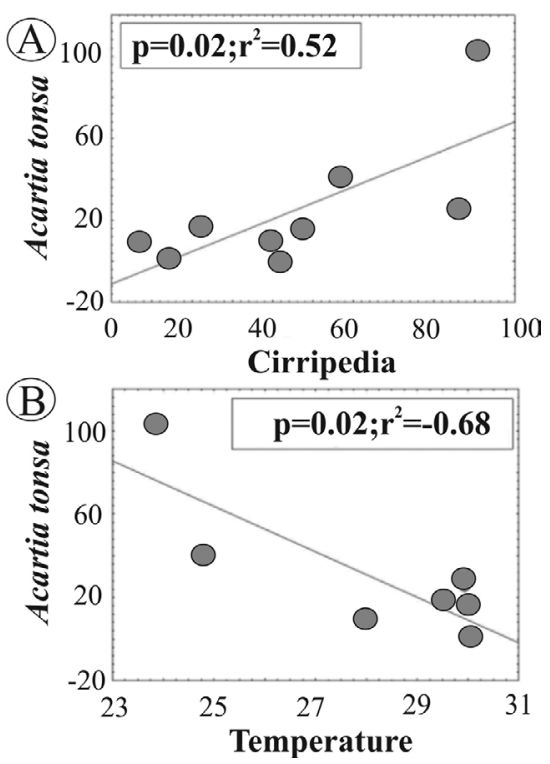

Figure 4. Temporal correlations between larvae of Cirripedia and Acartia tonsa (A) and between Acartia tonsa and temperature (B).
The Araruama lagoon had a low species richness: the meroplankton was represented by six groups and the holoplankton by 16 taxa. The zooplankton community showed a high relative abundance and frequency of both Cirripedia larvae (48.49\% relative abundance and $100 \%$ frequency of occurrence) and Acartia tonsa (18.78\% relative abundance or $89 \%$ frequency of occurrence). The meroplankton was represented by Ascidiacea, Cirripedia, Decapoda, Bivalvia, and Polychaete larvae. The holoplankton consisted of Creseis acicula, Limacina inflata, Subclass Ostracoda, Paracalanus quasimodo, Parvocalanus crassirostris, Acrocalanus monachus, $A$. tonsa, A. lilljeborgii, Temora turbinata, T. stylifera, Oithona hebes, O. simplex, Oncaea media, On. venusta, and a single specimen of Monstrilloida (all Copepoda) (Tab. 4).

Parvocalanus crassirostris was found in seasons 1 to 7 with minimum salinity of $35 \%$ and maximum of 55\%o, while T. turbinata was found only in March 2010 with salinity of $54 \%$. Monstrilla bahiana was found in station 4 in January 2011 at salinity of 46\%. The density of zooplankton varied from 3 ind. $\mathrm{m}^{-3}$ (station 8, March 2010) to 912 ind. $\mathrm{m}^{-3}$ (station 4, October 2010) with an average of $121 \pm 148$ ind.m ${ }^{-3}$ (Fig. 5).

Table 4. Relative abundance, frequency of occurrence, mean and standard deviation of all groups identified during the study period.

\begin{tabular}{|c|c|c|c|c|}
\hline Individuals & Abundance & Frequency & Mean & Deviation \\
\hline Hydromeduza & 0.10 & $6 \%$ & 1.80 & 0.60 \\
\hline Ascidian larvae & 1.79 & $19 \%$ & 11.80 & 10.32 \\
\hline Cirripedia larvae & 48.49 & $100 \%$ & 64.49 & 71.52 \\
\hline Decapoda larvae & 0.16 & $16 \%$ & 1.31 & 0.52 \\
\hline Bivalvia larvae & 0.01 & $1 \%$ & 1.00 & 0.11 \\
\hline Mytilidae larvae & 0.02 & $3 \%$ & 1.00 & 0.16 \\
\hline Polychaeta larvae & 0.04 & $4 \%$ & 1.33 & 0.27 \\
\hline Creseis acicula & 0.01 & $1 \%$ & 1.00 & 0.11 \\
\hline Limacina inflata & 0.02 & $3 \%$ & 1.00 & 0.16 \\
\hline Ostracoda & 0.02 & $3 \%$ & 1.00 & 0.16 \\
\hline Paracalanus quasimodo & 0.01 & $1 \%$ & 1.00 & 0.11 \\
\hline Parvocalanus crassirostris & 1.90 & $44 \%$ & 5.17 & 5.94 \\
\hline Acrocalanus monachus & 0.05 & $3 \%$ & 2.50 & 0.46 \\
\hline Acartia tonsa & 18.78 & $89 \%$ & 27.27 & 67.86 \\
\hline Acartia lilljeborghi & 0.01 & $1 \%$ & 1.00 & 0.11 \\
\hline Temora turbinata & 0.01 & $1 \%$ & 1.00 & 0.11 \\
\hline Temora stylifera & 0.01 & $1 \%$ & 1.00 & 0.11 \\
\hline Oithona oswaldocruzi & 0.26 & $15 \%$ & 2.17 & 1.09 \\
\hline Oithona simplex & 0.02 & $3 \%$ & 1.00 & 0.16 \\
\hline Oncaea media & 0.02 & $3 \%$ & 1.00 & 0.16 \\
\hline Oncaea venusta & 0.01 & $1 \%$ & 1.00 & 0.11 \\
\hline Monstrilla bahiana & 0.01 & $1 \%$ & 1.00 & 0.11 \\
\hline Copepodite & 26.58 & $93 \%$ & 40.32 & 66.23 \\
\hline Nauplius & 0.16 & $11 \%$ & 1.67 & 0.75 \\
\hline
\end{tabular}



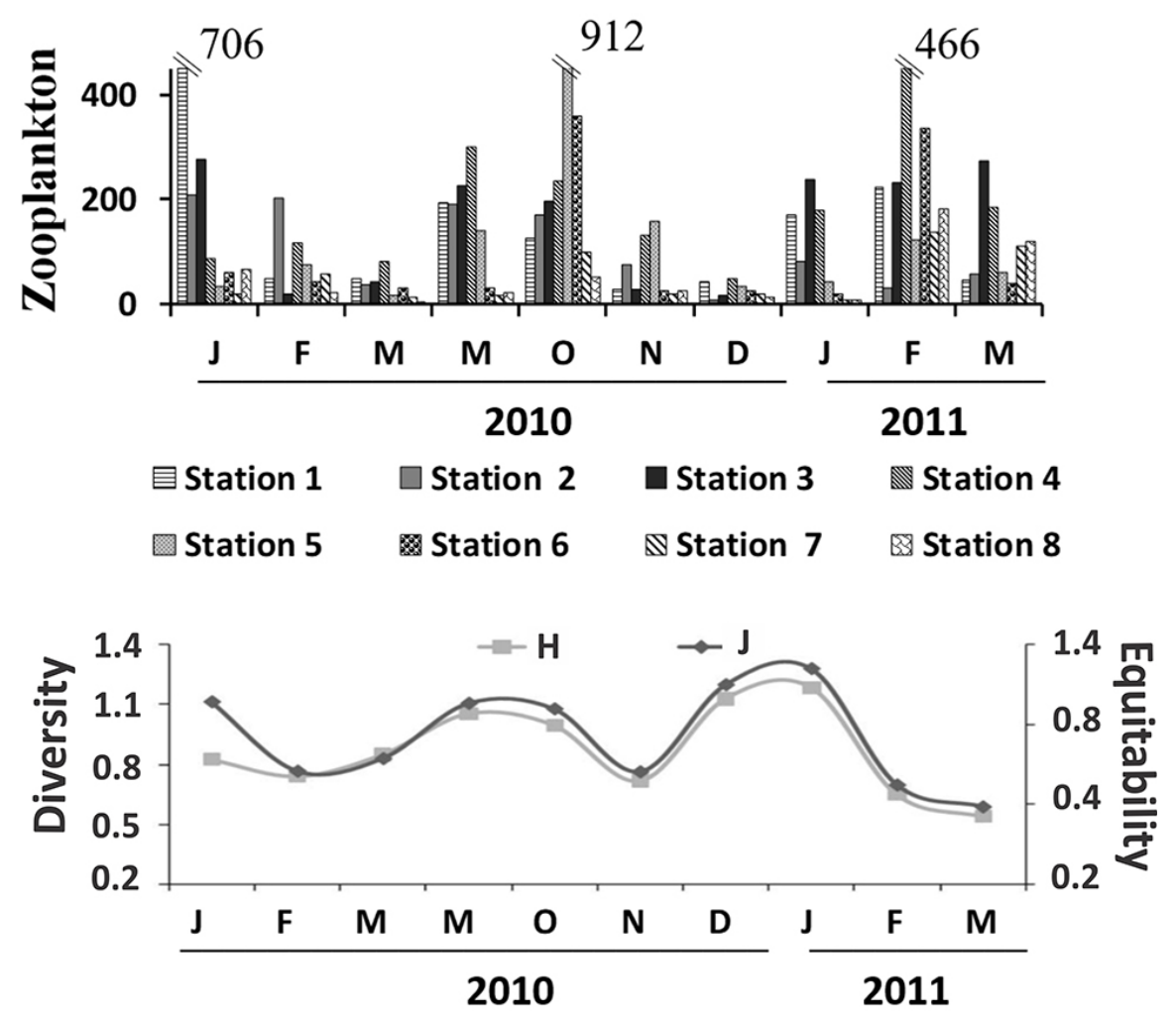

Figure 5. Variation of zooplankton density in each collection station, variations in the index of Shannon-Weaver which measures the Diversity $(\mathrm{H})$ and the Pielou's uniformity which measures the Equitability $(\mathrm{J})$ over the sampled months.

There is clear spatial variation (because the density varies considerably across the collection stations) in the density of zooplankton in the Araruama lagoon. In relation to the indices of community structure, richness was low and there was a high taxonomic similarity due to the dominance of Cirripedia and $A$. tonsa and the low contribution of other species. Equitability ranged from $\mathrm{E}_{\mathrm{H}}=0.39$ in March 2011 to $\mathrm{E}_{\mathrm{H}}=0.73$ in January 2011, with an overall average of $\mathrm{E}_{\mathrm{H}}=0.57 \pm$ 0.11 . Shannon diversity varied from 0.54 bits.ind $^{-1}$ in March 2011 to 1.18 bits.ind $^{-1}$, with an overall mean of $0.86 \pm 0.21$ bits.ind $^{-1}$ (Fig. 5).

\section{Discussion}

A low number of taxa was found during the study (Copepod, Pteropods [Order Thecosomata], Cirripedia larvae, Decapoda, and Polychaeta), when compared to past data from regions near the Araruama lagoon (Arraial do Cabo) (Rosa et al., 2016b). A previous study also found only three copepod genera (Coutinho et al., 1999). This may be associated with the high salinity of Araruama Lagoon (Rosa et al., 2016a).
Indeed, Wooldridge and Deyzel (2009) demonstrated that salinity and temperature are two of the main factors determining the spatio-temporal distribution of zooplankton. On a global scale, Buskey et al. (1998) claimed that hypersaline estuaries with salinity between $41 \%$ and $50 \%$ are usually characterized by low richness and low average abundance of zooplankton.

Over the study period, peaks in zooplankton abundance occurred during January 2010, October 2010, and February 2011, which were the months with the lowest salinities. These peaks may be related to peaks in phytoplankton abundance because, as mentioned by Souza et al. (2003), phytoplankton density is highest in the Araruama lagoon when the salinity is at its lowest. Studies with zooplankton have shown that when phytoplankton peaks are accentuated, the greater food availability consequently leads to an increase in the density of zooplankton (Fernandes et al., 2012; Highfield and Eloire, 2010; Rosa et al., 2016b).

The copepod assemblage is usually more abundant than the meroplanktonic larvae, but in the present study the Cirripedia larvae were almost always more abundant. Fernandes et al. (2012) showed that the 
Cabo Frio region has a high percentage of benthic invertebrates that have larval stages. However, the dominance of Cirripedia larvae in almost every study period was unexpected since the copepod assemblage is usually dominant along the coast of Brazil (Dias and Bonecker, 2008). The high relative abundance and frequency of occurrence of the copepod $A$. tonsa is a strong indicator of eutrophication (Coelho-Botelho et al., 1999). The constant temporal occurrence of this species in the lagoon suggests that $A$. tonsa is adapted to its conditions and can tolerate the high salinity and eutrophication. This species was also found in the Mar Menor in the Mediterranean by Gilabert (2001) and in the Madre Lagoon in South Texas, where high salinity adversely affected its populations (Buskey et al., 1998).

The species $P$. crassirostris and $O$. hebes are characteristic of Brazilian estuaries (Björnberg, 1981). Parvocalanus crassirostris is a species that has a great tolerance to high salinity and temperatures (Mageed, 2006) and is found in several parts of the world (Montú, 1980; Björnberg, 1981; Mageed, 2006; Alajmi et al., 2015) but is limited to the coastal waters of tropical and subtropical regions. It is one of the most common copepods in the coastal and estuarine waters of Brazil (Montú, 1980).

An individual of copepod from the order Monstrilloida (M. bahiana) was found in the lagoon in summer at a salinity of $46 \%$. Although representatives of Monstrilloida are widely distributed, they are poorly known compared to other planktonic copepods. This is mainly due to the rarity of individuals caught in trawls as they are only planktonic as adults (Dias and Bonecker, 2007). Their life cycle is different from other copepods because the larvae parasitize a considerable variety of benthic macroinvertebrates, such as polychaetes, mollusks, and other invertebrates (Grygier and Ohtsuka, 2008). Adults are planktonic and incapable of feeding. They live for a short period and only to reproduce (Suárez-Morales and PalomaresGarcía, 1995). This is the first record of this order in the region of Cabo Frio (Valentin et al., 1987; MonteiroRibas and Mureb, 1991; Rosa et al., 2016b; Rosa and Monteiro-Ribas, 2012; Rosa et al., 2019).

The copepod T. turbinata was recorded in low densities in the Araruama lagoon. This species has been cited as one of the most dominant species in estuarine environments and has an extensive distribution along the Brazilian coast (Santos et al., 2009; Rosa et al., 2016b). Temora turbinata is considered as an invader off the Brazilian coast and was first mentioned in the 1980s in the northeast part of the country, and later recorded in the south. Consequently, this species seems to have adapted well to the environmental conditions of the Atlantic and has expanded its distribution along the Brazilian coast (Villac et al., 2009). The holoplankton at Araruama lagoon was represented only by Copepoda, Pteropoda and Hydromedusa groups. This demonstrates that the holoplankton diversity of the lagoon is poorer than that of meroplankton, with the notable absence of groups commonly reported in other estuaries as well as in the Cabo Frio region, such as Cladocera, Ostracoda, Appendicularia and Chaetognatha (Santos et al., 2009; Rosa et al., 2016b; Araujo et al., 2017). Species of Appendicularia and Ctenophora were previously found at high salinities in the Mar Menor, region of the Mediterranean Sea (Gilabert, 2001), revealing that they can survive in hypersaline environments. However, the species present in the Cabo Frio region could not withstand the conditions of the lagoon.

When exposed to the atypically higher temperatures of the Araruama lagoon the results demonstrate a lower release of the Cirripedia larvae, which may be related to the preference to release larvae at lower temperatures. According to Fernandes et al. (2012), meroplanktonic larvae may also have peaks in cold water periods and associated with phytoplankton peaks. In addition, the larvae also prefer an acidic $\mathrm{pH}$ which corroborates the work of Pansch et al. (2013), who found that the survival rate of Cirripedia larvae was greater at lower $\mathrm{pH}$ levels. In this study, six groups of larvae were found: ascidians, cirripedians, decapods, bivalves, Mytilidae, and polychaetes. Comparatively, on the island of Cabo Frio, which is located near the lagoon, nine groups of larvae were found including Ostreidae, Isognomonidae, and Bryozoa, which were absent in Araruama lagoon (Oliveira et al., 2015). Cirripedia larvae were the most representative group in terms of abundance in the present work, but in Fernandes et al. (2012) and Oliveira et al. (2015), the larvae of Mytilidae were found to be just as abundant as Cirripedia. In contrast, we found Mytilidae larvae to be almost absent, especially at the innermost stations. 


\section{CONCLUSION}

After analyzing the data, it is evident that the spatial variation of the Cirripedia larvae is directly influenced by abiotic factors. The Cirripedia have higher salinity, lower temperature and $\mathrm{pH}$ as the main factors that influence their preference for environments and an inversely proportional relationship with the opposite conditions (low salinity, high temperature and $\mathrm{pH}$ ). The distribution of cirripedes in Araruama lagoon seems to follow the same pattern regarding the gradient of these abiotic factors along the lagoon. The low quantity of taxa presented in the lagoon when compared to geographically close environments, such as Cabo Frio, seems to be related to the ability of the species to acclimate to the extreme conditions. Few species can adapt to the conditions found in the lagoon, particularly those of salinity and temperature. New studies are needed to precisely define if the abiotic factors work in isolation in the zooplankton assembly or if they are correlated factors, as well as their specific impact on the biomass and trophic dynamics of the environment.

\section{ACKNOWLedgemENTS}

The authors wish to thank the Intermunicipal Consortium Lagos São João, which funded the study, and Prolagos, which analyzed the physicochemical parameters.

\section{References}

Alajmi, F.; Zeng, C. and Jerry, D.R. 2015. Domestication as a novel approach for improving the cultivation of calanoid copepods: A Case Study with Parvocalanus crassirostris. PLoS ONE, 10: 1-16.

Araujo, A.V.; Dias, C.O. and Bonecker, S.L.C. 2017. Differences in the structure of copepod assemblages in four tropical estuaries: Importance of pollution and the estuary hydrodynamics. Marine Pollution Bulletin, 115: 412-420.

Aslan, J.F.; Pinto, A.E.M. and Oliveira, M.M. 2017. Poluição do meio ambiente marinho: um breve panorama dos princípios, instrumentos jurídicos e legislação brasileira. Planeta Amazônia: Revista Internacional de Direito Ambiental e Políticas Públicas, 9: 175-186.

Björnberg, T.S.K. 1981. Copepoda.p. 587-679. In: D. Boltovskoy (ed), Atlas del Zooplancton del Atlántico Sudoccidental y Métodos de Trabajo con el Zooplancton Marino. Mar del Plata, INIDEP, 2.
Boltovskoy, D. 1999. South Atlantic Zooplankton. Leiden, Backhuys Publishers, 1705p.

Boltovskoy, D.C. 1981. Atlas del Zooplancton del Atlántico Sudoccidental y Métodos de Trabajo con el Zooplancton Marino. Mar del Plata, INIDEP, p. 869-1098.

Buskey, E.J.; Wysor, B. and Hyatt, C. 1998. The role of hypersalinity in the persistence of the Texas 'brown tide' in the Laguna Madre. Journal of Plankton Research, 20: 1553-1565.

Carvalho, A.P.A.M.; Costa, R.S. and Rosa, J.C.L. 2014. Eutrophication and introduction of exotic species in hypersaline estuary. Proceedings of IV Seminário Regional Sobre Gestão de Recursos Hídricos, 28 a 30 de Outubro, 13p. Campos dos Goytacazes, RJ, UPEA/IFF, CD-ROM ISSN 2316-5049.

Castro, M.S.; Bonecker, A.C.T.; Valentin,J.L. 1999. Ichthyoplankton of a permanently hypersaline coastal lagoon: Lagoa de Araruama, Brazil. Journal of Tropical Ecology, 40: 221-227.

Centro de Hidrografia da Marinha - Marinha do Brasil. Available at: <https://www.marinha.mil.br/chm/tabuas-de-mare>. Accessed on 15 June 2011.

Coelho-Botelho, M.J.; Mauro, J.B.N.; Dias, C. de O.; Kurtz, F.W.; Truzzi, A.C.; Nogueira, C.R.; Reis, J.L. dos and Mathias, A.M. da F. 1999. Aspectos do zooplâncton na baía de Sepetiba (RJ, Brasil).p. 1-33. In: S.H.G. Silva and H.P. Lavrado (eds), Ecologia dos Ambientes Costeiros do Estado do Rio de Janeiro, ser. Oecologia Brasiliensis. Rio de Janeiro, PPGE-UFRJ, 7.

Costa, J.A.; Souza, J.P.; Teixeira, A.P.; Nabout, J.C. and Carneiro, F.M. 2018. Eutrophication in aquatic ecosystems: a scientometric study. Acta Limnologica Brasiliensia, 30: e2.

Costa, M.A.M. 2015. Da lama ao caos: um estuário chamado Baía de Guanabara. Cadernos Metrópole, 17: 15-39.

Cotner, J.B.; Suplee, M.W.; Chen, N.W.; Shormann, D.E. 2004. Nutrient, sulfur and carbon dynamics in a hypersaline lagoon. Estuarine Coastal and Shelf Science, 59: 639-652.

Coutinho, R.; Ribeiro, P.; Kjerfve, B.; Knoppers, B.; Muehe, D. and Valentin, J. L. 1999. Araruama: uma lagoa ameaçada. Ciência Hoje, 25: 24-31.

Dias, C. and Bonecker, S.L.C. 2008. Inter-annual variability of planktonic copepods in a tropical bay in southeastern Brazil. Brazilian Archives of Biology and Technology, 51: 531-542.

Dias, C.O. and Bonecker, S.L.C. 2007. Study of Monstrilloida distribution (Crustacea, Copepoda) in the Southwest Atlantic. Pan-American Journal of Aquatic Sciences, 2: 270-278.

Fernandes, L.D.A.; Quintanilha, J.; Monteiro-Ribas, W.; Gonzalez-Rodriguez, E. and Coutinho, R. 2012. Seasonal and interannual coupling between sea surface temperature, phytoplankton and meroplankton in the subtropical southwestern Atlantic Ocean. Journal of Plankton Research, 34: 236-244.

Gilabert, J. 2001. Seasonal plankton dynamics in a Mediterranean hypersaline coastal lagoon: The Mar Menor. Journal of Plankton Research, 23: 207-217.

Grygier, M.J. and Ohtsuka, S. 2008. A new genus of monstrilloid copepods (Crustacea) with anteriorly pointing ovigerous spines and related adaptations for subthoracic brooding. Zoological Journal of the Linnean Society, 152: 459-506.

Highfield, J.M. and Eloire, D. 2010. Seasonal dynamics of meroplankton assemblages at station L4. Journal of Plankton Research, 34: 236-244. 
Kirby, R.R.; Beaugrand, G. and Lindley, J.A. 2008. Climateinduced effects on the meroplankton and the benthic-pelagic ecology of the North Sea. Limnology and Oceanography, 53: 1805-1815.

Kordas, R.L.; Harley, C.D.G. and O’Connor, M.I. 2011. Community ecology in a warming world: The influence of temperature on interspecific interactions in marine systems. Journal of Experimental Marine Biology and Ecology, 400: 218-226.

Mageed, A. 2006. Spatio-Temporal Variations of Zooplankton Community in the Hypersaline Lagoon of Bardawil, North Sinai, Egypt. Egyptian Journal of Aquatic Research, 32: 168-83.

Monteiro-Ribas, W.M. and Mureb, A.M. 1991. Larvas de mexilhão Perna perna em Arraial do Cabo (RJ). Nerítica, 6: 27-41.

Montú, M. 1980. Zooplâncton no estuário da Lagoa dos Patos. I. Estrutura e variações temporais e espaciais da comunidade. Atlântica, 4: 53-72.

Muehe, D. 2006. Gênese da morfologia do fundo da lagoa de Araruama e cordões litorâneos associados. Proceedings of the VI Simpósio Nacional de Geomorfologia/Regional Conference on Geomorphology, Goiânia-GO, September 6-10, 2006. Available at http://1sie.unb.br/ugb/app/ webroot/sinageo/6/6/271.pdf. Accessed on 23 March 2019.

Oliveira, M.M.F.; Pereira, G.C.; Ebecken, N.F.F. and Oliveira, J.L.F. 2015. Multivariate Analysis of Extreme Physical, Biological and Chemical Patterns in the Dynamics of Aquatic Ecosystem. Journal of Environmental Protection, 6: 885-901.

Pansch, C.; Schlegel, P. and Havenhand,J. 2013.Larval development of the barnacle Amphibalanus improvisus responds variably but robustly to near-future ocean acidification. ICES Journal of Marine Science, 70: 805-811.

Pereira, L.F.M. 2007. A gestão participativa no caso do saneamento da região dos Lagos, Rio de Janeiro. Revista Discente Expressões Geográficas, 3: 10-41.

Rosa, J.C.L.; Alberto, M.D.; Monteiro-Ribas, W M.; Neves, M.H.C.B. and Fernandes, L.D.A. 2016a. Spatial variability in the icthyoplankton structure of a subtropical hypersaline lagoon. Brazilian Journal of Oceanography, 64: 149-156.

Rosa, J.C.L. and Monteiro-Ribas, W.M. 2012. Ocurrence record of Pontella marplatensis copepod in Arraial do Cabo RJ - Brazil. Biotemas, 25: 197-98.

Rosa, J.C.L.; Monteiro-Ribas, W.M. and Fernandes, L.D.A. 2016b. Herbivorous copepods with emphasis on dynamic Paracalanus quasimodo in an upwelling region. Brazilian Journal of Oceanography, 64: 67-74.
Rosa, J.C.L.; Monteiro-Ribas, W.M.; Batista, L.L. and Fernandes, L.D.A. 2019. First record of Oithona attenuata Farran, 1913 (Crustacea: Copepoda) from Brazil. Nauplius, 27: e2019001.

Santos, T.G.; Gusmão, L.M.O.; Neumann-Leitão, S. and Cunha, A.G. 2009. Zooplâncton como indicador biológico da qualidade ambiental nos estuários dos rios Carrapicho e Botafogo, Itamaracá - PE. Revista Brasileira de Engenharia de Pesca, 4: 45-56.

Serpe, F.R.; Adloff, C.T.; Crispim, M.C and Rocha, R.M. 2010. Comunidade zooplanctônca em um estuário hipersalino no nordeste do Brasil. Revista Brasileira de Engenharia de Pesca, 5: 51-73.

Silva e Silva, L.H.; Senra, M.C.E.; Faruolo, T.C.L.M.; Carvalhal, S.B.V.; Alves, S.A.P.M.N.; Damazio, C.M.; Shimizu, V.T.A.; Santos, R.C and Iespa. A.A.C. 2004a. Composição paleobiológica e tipos morfológicos das construções estromatolíticas da lagoa vermelha, RJ, Brasil. Revista Brasileira de Paleontologia, 7: 193-198.

Silva e Silva, L.H.; Senra, M.C.E.; Faruolo, T.C.L.M.; Carvalhal, S.B.V.; Alves, S.A.P.M.N.; Damazio, C.M.; Shimizu, V.T.A.; Santos, R.C and Iespa. A.A.C. 2004b. Estruturas microbianas recentes da lagoa Pernambuco, estado do Rio de Janeiro, Brasil. Revista Brasileira de Paleontologia, 7: 189-192.

Souza, M.F.L.; Kjerfve, B.; Knoppers, B.; Landim de Souza, W.F. and Damasceno, R.N. 2003. Nutrient budgets and trophic state in a hypersaline coastal lagoon: Lagoa de Araruama, Brazil. Estuarine, Coastal and Shelf Science, 57: 843-858.

Suárez-Morales, E. and Palomares-García, R. 1995. A new species of Monstrilla (Copepoda: Monstrilloida) from a coastal system of the Baja California Peninsula, Mexico. Journal of Plankton Research, 17: 745-752.

Valentin, J.L.; Monteiro-Ribas, W.M.; Mureb, M.A.; Pessotti, E. 1987. Sur quelques zooplanctontes abondantes dans l'upwelling de Cabo Frio (Brésil). Journal of Plankton Research, 9: 1195-1216.

Villac, M.C.; Lopes, R.M.; Rivera, I.N.G.; Bassanello, R.T.; Cunha, D.R.; Martinelli-Filho, J.E. and Santos, D.B. 2009. p. 39-104. Plâncton. In: R.M. Lopes (ed), Informe sobre as espécies exóticas invasoras marinhas no Brasil. Brasilia, MMA/SBF. [Série Biodiversidade, 33]

Wooldridge, T.H. and Deyzel, S.H.P. 2009. Temperature and salinity as abiotic drivers of zooplankton community dynamics in the Great Berg Estuary. Transactions of the Royal Society of South Africa, 64: 219-237. 